\title{
Procathepsin D in cancer development
}

\author{
Vaclav Vetvicka \\ Correspondence: vaclav.vetvicka@louisville.edu \\ University of Louisville, Department of Pathology, Louisville, KY 40202 USA.
}

\begin{abstract}
Over thirty years of research showed that procathepsin D is overexpressed and secreted by cells of several tumor types including lung, breast and prostate cancer. After secretion, it exhibits growth factor -like mitogenic activity. Subsequent in vivo and in vitro studies strongly support the hypothesis that the mitogenic effects are mediated via its activation peptide. Another potential cancer-related role of procathepsin $\mathrm{D}$ is the effect on resistance of cancer cell to chemotherapeutic drugs. The purpose of this review is to summarize the two major roles of procathepsin $\mathrm{D}$ in cancer development.
\end{abstract}

Keywords: Cathepsin D, procathepsin D, activation peptide, cancer, breast, lung, prostate, proliferation, siRNA, growth factro

\section{Introduction}

History of aspartic proteinases and recognition of their role in human physiology was marked by the work of Theodor Schwann [1], who recognized the proteolytic activity of the gastric juice and gave it the name pepsin. Later, Hedin described a proteinase present in bovine spleen with activity in higher acidic range [2]. This enzyme was later named cathepsin D. With subsequent improvements in isolation techniques and biochemical characterization, more and more members of this family of proteolytic enzymes were established. The most important aspartic proteinases are represented by pepsin A, gastricsin, renin, cathepsin D, cathepsin E and HIV and retroviral proteinases.

These proteinases are widely distributed in organisms and accomplish various functions. However, they share common features such as low $\mathrm{pH}$ of action and sensitivity to three specific inhibitors - pepstatin A, diazoacetyl norleucine methylester, and 1,2-epoxy-3-(p-nitrophenoxy) propane. Another common feature is the high similarity of their primary structures. Mature aspartic proteinase consists of a chain of app. 300 amino acid residues, with the resulting molecular weight around 35, 000 $\mathrm{Da}$, that is often dependent on the degree of glycosylation. Regarding the activation, three possible routes are involved: total self-activation, self-activation complemented by assisted activation, and totally activated activation [3]. Readers seeking detailed information should see [4].

The subject of this review is aspartic proteinase cathepsin D (CD), and its involvement in cancer. Its name comes from the Greek kata- "down from" and hepsein "boil" and also "digest food", based on [5] who introduced this term for an intracellular peptidase with acidic $\mathrm{pH}$ optimum. Subsequent studies showed that the protein is formed by two peptidic chains with a proform of higher molecular weight as a precursor of the final hydrolytically processed form. The existence of an inactive precursor (procathepsin D; pCD) was later confirmed [6,7]. In the following years, numerous studies were focused toward several directions: intracellular trafficking and processing of pCD was studied $[6,8,9]$, characterization of the gene of human $C D[10,11]$ and determination of the three-dimensional structure $[12,13]$.

Cathepsin D cleaves denatured polypeptides in an endopeptidase mode of action with hydrophobic amino acids at the scissile bond [14]. As specific inhibitor, pepstatin, a reversible peptidomimetic inhibitor of aspartic peptidases, inhibits cathepsin D with $K_{i}$ in pM range [15]. A significant number of $C D$ inhibitors was developed based on pepstatin structure and its statin residue which acts as a transition-state mimic [16]. With respect to structure and formation, CD is synthesized in rough endoplasmic reticulum in the form of pre-pro-enzyme precursor which is about 400 amino acids long. The primary structure of human CD precursor $(52 \mathrm{kDa})$ is posttranslationally modified by two major processes - proteolytic cleavage and glycosylation. Proteolytical removal of the signal peptide occurs during the translocation across the membrane of the rough endoplasmatic reticulum. Procathepsin D is then targeted to lysosomes where, upon acidification, undergoes proteolytic activation. The activation processing of $\mathrm{pCD}$ requires proteolytic removal of the activation peptide from the zymogen molecule $[8,9]$. Subsequently, CD is subjected to additional proteolytic processing which converts the single-chain molecule into

(C) 2012 Vaclav Vetvicka; licensee Herbert Publications Ltd. This is an open access article distributed under the terms of Creative Commons Attribution License (http://creativecommons.org/licenses/by/3.0), This permits unrestricted use, distribution, and reproduction in any medium, provided the original work is properly cited. 
two-chain molecule formed by heavy and light chains (34 $\mathrm{kDa}$ and $14 \mathrm{kDa}$, respectively). The cleavage is likely to be performed by other lysosomal peptidases [17].

Cathepsin D is a glycoprotein with two $\mathrm{N}$-linked oligosaccharides of high-mannose type $[7,18]$. The glycosylation is not required for the enzyme activity or folding but plays a significant role in its targeting, as the oligosaccharides are tagged by mannose-6-phosphate residues (for review see [19]). These tags allows for lysosomal targeting of $C D$ via mannose6-phosphate receptors [20]. However, an alternative transport associated with prosaposin has also been proposed [21].

\section{Biological actions of cathepsin D}

Cathepsin $D$ has been described to be expressed in practically all tissues and organs and it was localized in lysosomes and in most prelysosomal compartments. In the early stage of $C D$ research, the intracellular digestion of proteins has been postulated as its major function. However, data achieved over the last decades changed our understanding of the complex roles that cathepsin D plays both in physiology and pathology (for a review see [22,23]. Knock-out experiments demonstrated the importance of $C D$ in the cell and tissue growth regulation which is supported by participation in tissue remodeling [24]. Physiological and pathophysiological actions of $C D$ are usually controversial. In apoptosis, some studies based on KO model showed anti-apoptotic properties $[\mathbf{2 5}, \mathbf{2 6}]$. The anti-apoptotic properties of $C D$ are also suggested to be responsible for $C D$ protection of cancer cells treated with cytotoxic drugs [27]. However, pro-apoptotic functions of $C D$ are now the subject of a growing number of studies which showed that the addition of CD to mitochondria resulted in substantial ROS generation and cyt c production [28] and that hydrogen peroxide cytotoxicity was mediated via $\mathrm{CD}$ mediated intralysosomal degradation of thioredoxin-1 [29].

Additional role of $C D$ can be found in neurodegenerative diseases such as Alzeheimer disease and retinal atrophy, where the proteolytic activity of $C D$ protected the development of type AA amyloid fibrils [30].

Increased levels of CD (both at the mRNA and protein levels) were first reported in several human neoplastic tissues almost 30 years ago [31,32]. These findings generated intense research in a possible role for $C D$ in neoplastic processes. A strong predictive value was found for $C D$ concentrations in breast cancer as well as many other tumor types [33-35]. However, despite numerous studies suggesting involvement of $C D$ [36], the direct enzymatic involvement of mature enzyme in the invasiveness of cancer has never been demonstrated $[37,38]$. Later studies further questioned the basis for the prognostic value of $C D$ concentrations. At any given time, three different components of $C D$ are present: a) pCD; b) mature enzyme $C D$; and c) mature $C D$ at different stages of proteolytic processing. Furthermore, the monoclonal antibodies that have been used for visualization of $C D$ react with both $C D$ and $p C D$.

\section{Procathepsin D in cancer}

The primary structure of a human $\mathrm{PCD}$ (enzymatically inactive; $52 \mathrm{kDa}$ ) is posttranslationally modified by two major processes - proteolytic cleavage and glycosylation. Removal of the signal peptide occurs during the translocation across the membrane of the rough endoplasmatic reticulum. Procathepsin $D$ is then targeted to lysosomes and, upon acidification, undergoes activation processing requiring proteolytic removal of the activation peptide. This has been described to proceed both in an autocatalytic mode or with the assistance of other lysosomal enzymes [8]. The self-activation produces so-called pseudo-cathepsin $D(51 \mathrm{kDa})$ that is enzymatically active but contains a portion of the activation peptide $[39,40]$.

When it became clear that the fully mature enzyme $C D$ has probably no direct role in cancer development [41], attention focused back on the original finding of overexpression of pCD in cancer cells. However, some new studies seem to suggest that cathepsin D might affect cancer growth by interaction with heat shock cognate 70 protein [42]. We would like to point out that this paper did not really showed if the responsible molecule is $\mathrm{pCD}$ or fully matured $\mathrm{CD}$. Our own work initially focused on the question of whether pCD influenced growth of cancer cells with the working hypothesis that the pCD may function as a mitogen. Our experiments showed strong mitogenic activities of $\mathrm{pCD}$ which can specifically be inhibited by addition of anti-pCD antibodies. Numerous controls showed that mannose-6-phosphate receptors are not involved, as neither mannose-6-phosphate, soluble receptor or anti-mannose-6-phosphate receptor antibodies have any effects on inhibition of pCD-promoted cancer growth [43]. Studies of Glondu et al., [44] further supported the fact that the amount of $\mathrm{pCD}$ synthesis strongly corresponds with the mitogenic properties of cancer cells.

Subsequent experiments were oriented toward deeper understanding of the responsible moiety of the $\mathrm{PCD}$ molecule. As the $C D$ was not active, the only difference between $P C D$ and $C D$ was the activation peptide. Using synthetic activation peptide, we demonstrated that the $\mathrm{pCD}$-related effects were in fact caused by this molecule. Subsequently, we prepared individual fragments of the activation peptide and specific monoclonal antibodies and demonstrated that the growth factor activity of activation peptide is localized in nine amino acid stretch (AA 36-44) of the activation peptide molecule [45]. We demonstrated that the activation peptide itself stimulates growth of breast, prostate and lung cancer cells in vitro and in vivo as much as native $\mathrm{PCD}$ molecule [46-49].

The role of $\mathrm{pCD}$ in cancer has also been shown in vivo. The original experiments have been done by Rochefort's group. Using rat tumor cells transfected with human $\mathrm{pCD}$ vector, Garcia et al., showed the increased metastasis corresponding to the level of pCD DNA expression [50]. Our group used different experimental design employing athymic nude mice injected with human estrogen receptor-negative breast cancer cell 
Vaclav Vetvicka Journal of Cancer Therapeutics \& Research 2012,

http://www.hoajonline.com/journals/pdf/2049-7962-1-22.pdf

line MDA-MB-231. Upon establishing the cancer growth, we injected these mice with synthetic microspheres containing anti-activation antibodies and found inhibited growth of human cancer cells up to 8 weeks after injection [51].

In our subsequent studies, we focused our attention on the possibilities to regulate $\mathrm{pCD}$ synthesis or release from cancer cells. We prepared numerous clones of four different breast cell lines and, using several types of genetic manipulations, we obtained clones with either higher, lower or no secretion of pCD. In all cases we managed to show that the level of pCD fully reflects cancerogenic properties of the cells [51-54]. Additional experiments confirmed that the downregulation of $p C D$ expression by antisense gene inhibited lung metastasis of breast cancer cells but had no effect on invasion in vitro [44]. In addition, Tedone et al., showed that downregulation of $\mathrm{pCD}$ expression resulted in decreased invasion of MCF-7 cells in vitro [36].

To further analyze the biological effects of the whole $p C D$ molecule, we prepared cDNA vectors producing entire $P C D$, active-site mutated $\mathrm{PCD}, \mathrm{pCD}$ without activation peptide, and pCD mutated in the activation peptide region. In addition, we prepared these clones in three different breast cancer cells. Using a series of $\mathrm{PCD}$ mutants stably transfected in breast cancer cells, we managed to clarify the molecular basis of $\mathrm{pCD}$ actions that is clearly associated with the activation peptide structure. For this purpose, we used two different approaches. First, using the above mentioned transfected lines, we evaluated proliferative potential of each transfected cell line in MTT assay and showed clear correlation between pCD secretion and proliferative effects. Next, we used these clones in cancer growth experiments. For this purpose, we designed catalytically inactive ribozymes by changing the G-A in the catalytic domain, and suppressed the $\mathrm{pCD}$ expression. To ensure that the downregulation of $p C D$ was due to the ribozyme activation, RT-PCR analysis was performed using $\mathrm{PCD}$, $\mathrm{RZ}$ and actin primers. The anti-pCD ribozymes were capable of downregulating pCD mRNA expression significantly by $60 \%$, while no change was observed in control RZ- or empty vectortransfected cells. When the synthesis of pCD was inhibited by specifically designed ribozymes, the proliferation of breast cancer cells was suppressed in all four cases. Similar results were later achieved using siRNA inhibition $[\mathbf{5 5}, \mathbf{5 6}]$.

To answer the question whether the expressed $p C D$ and its individual mutants are proteolytically active, the conditioned media of cells expressing wild-type and various mutants of pCD were analyzed for proteolytic activity. In order to finally prove AP's importance for mitogenic activity of $p C D$, we introduced several single point mutations into region of AP. The mutations were focused on the region crucial for binding. These mutants had similar proteolytic activity as native $\mathrm{PCD}$, which is evidence of their correct folding, but lacked the mitogenic activity. By this experiment, we have proved on a molecular level the mitogenicity responsible part of $\mathrm{pCD}$.
In case of HBL-100 clones, wild-type pCD, monoglycosylated and non-glycosylated mutants of $\mathrm{pCD}$ displayed proteolytic activity, whereas mutated $\mathrm{pCD}$ failed to exhibit any proteolytic activity. Further, pCD completely without activation peptide was found to be catalytically inactive [56].

In order to assess the effect of various mutations of $p C D$ on proliferation of breast cancer cells, expressed $\mathrm{pCD}$ and its mutants were affinity purified. Using a proliferation assay, we found that purified $\mathrm{pCD}$ along with monoglycosylated mutants stimulated proliferation in the three cell lines tested, but PCD lacking the activation peptide or $\mathrm{pCD}$ with mutated activation peptide had no activity.

Based on all the presented data, we can conclude that pCD acts as a mitogenic factor for cancer cells, and that this activity is mediated via its activation peptide. The level of glycosylations plays no significant role [56-58]. The mechanism of these autocrine mitogenic effects of pCD is still not fully known. We proposed that the mitogenic function is related to extracellular presence of $\mathrm{pCD}$ interacting with a thus far unknown receptor. This interaction leads to activation of NFKB. The question of $\mathrm{pCD} / \mathrm{CD}$ receptor remains unclear. Most papers showed that the common mannose-6-phosphate receptor is not involved in effects of these molecules on cancer [41], but efforts to find and characterize the receptor were not successful. Only recently, the results of Beaujouin et al., [59] showed that $\mathrm{pCD} / \mathrm{CD}$ interacts by a domain around the connection of heavy and light chains of CD with LPR1 receptor and this interaction leads to promoted growth of fibroblasts. The binding moiety on cancer cells remains a mystery.

In adition to the direct effects of pCD on cancer cells, recent reports suggested another possible role of $\mathrm{pCD}$ in regulation of cancer growth. Beaujouin et al., used 3Y1-Ad12 cancer cells and etoposid and concluded that overexpression of pCD enhanced the etoposid induced apoptosis and decreased the chemoresistance of the cells while concurrently showing that this induction of apoptosis is not connected to the proteolytic activity of CD [60]. On the other hand, Sagulenko used neuroblastoma cells and doxorubicin as chemotherapeutic agents and demonstrated that the high secretion of $\mathrm{PCD}$ leads to chemoresistance to doxorubicin which is brought on by high anti-apoptotic signaling caused by pCD [27]. We followed up these studies using three different breast cancer cell lines, ZR-75-1, MCF-7 and and MDA-MB-231 cells which were transfected by either native $P C D$ or $p C D$ mutated at different positions (as mentioned above). We tested the chemosensitivity of these cell lines to common chemotherapeutic drugs 5 -fluorouracil, doxorubicin and cyclophosphamid and asked whether the overexpression of pCD leads to a) changes in resistence; b) whether the resistance is consequence of intra- or extracellular effects of pCD; and c) if there is any correlation with apoptosis. We have used three different chemotherapeutic substances with 
different primary cytostatic mechanisms of action but with the same apoptotic ending.

Our study clearly showed that pCD expression level correlates with the resistance to tested chemotherapeutic drugs. The control cells (empty vector) have not shown any changes in the resistance and at the same time excluded the possibility that the changes in resistance are caused by some effects of the transformation. Another supporting fact indicating a positive influence of $\mathrm{pCD}$ overexpression on the resistance is based on results of silencing the $p C D$ production in the parent cell line-the silencing dramatically increased the sensitivity to all three drugs. Based on this observation, we proposed that the resistance involves the extracellular functions of $\mathrm{pCD}$. This can be documented by the activity of antibodies (which are acting extracellulary) and by the increased resistence when external pCD is added to the media of native cells or cells transfected with siRNA inhibiting the translation of $\mathrm{pCD}$. The experiment testing the effects of Brefeldin (which inhibits secretion of proteins) also supports these conclusions [61]. Based on these results, we concluded that the production of $\mathrm{pCD}$ has influence on the chemoresistance. The mechanisms of these actions are not clear and experiments trying to characterize these mechanisms are currently under way.

\section{Conclusion}

From three decades of intensive research, one can conclude that $\mathrm{pCD}$ has significant effects on cancer progression, both directly via interaction with cancer cells-related receptor and indirectly via increased chemoresistance of tumor cells. Additional role of pCD in stromal cells (both overexpression and possible interaction) is possible, but currently not fully documented. The roles of the PCD could, in fact, be an important fact for prediction of resistence and help in selection of optimal chemotherapy.

\section{Competing interests}

The authors declare that they have no competing interests.

Publication history

Received: 05-June-2012 Revised: 19-July-12

Accepted: 09-Aug-2012 Published: 17-Aug-2012

\section{References}

1. Schwann T. Uber das wesen des Verdauungsprocesses. Arch. Anast. Phys. Wiss. Med. 1836; 90:176-196.

2. Hedin SG. Investigation on the proteolytic enzymes of the spleen of the ox. J.Physiol. 1904; 30: 155-165.

3. Koelsch G, Mares M, Metcalf $P$, Fusek M: Multiple functions of pro-parts of aspartic proteinase zymogens. FEBS Lett 1994; 343;(1.);6-10. | Article I PubMed

4. Fusek M, Vetvicka V. Aspartic Proteinases. Physiology and Pathology. Boca Ration, CRC Press, 1995.

5. Press EM, Porter RR, Cebra J: The isolation and properties of a proteolytic enzyme, cathepsin D, from bovine spleen. Biochem J 1960 . 74;(501-14. | PubMed Abstract | PubMed Full Text

6. Erickson $\mathrm{AH}, \mathrm{Blobel} \mathrm{G}$ : Early events in the biosynthesis of the lysosomal enzyme cathepsin D. J Biol Chem 1979; 254;(23.);11771-4. | Article |
PubMed

7. Hasilik A, Neufeld EF: Biosynthesis of lysosomal enzymes in fibroblasts. Synthesis as precursors of higher molecular weight. J Biol Chem 1980; 255;(10.);4937-45. | Article | PubMed

8. Hasilik A, von Figura K, Grzeschik KH. Assignment of gene for human cathepsin D to chromozome 11. Cytogenet. Cell. Genet. 1982; 32: 284.

9. Gieselmann V, Hasilik A, von Figura K: Processing of human cathepsin D in lysosomes in vitro. J Biol Chem 1985; 260;(5.);3215-20. I Article I PubMed

10. Faust PL, Kornfeld S, Chirgwin JM: Cloning and sequence analysis of cDNA for human cathepsin D. Proc Natl Acad Sci U S A 1985; 82;(15.);4910-4. | Article | PubMed Abstract | PubMed Full Text

11. Augereau P, Garcia M, Mattei MG, Cavailles V, Depadova F, Derocq D, et al.: Cloning and sequencing of the $52 \mathrm{~K}$ cathepsin D complementary deoxyribonucleic acid of MCF7 breast cancer cells and mapping on chromosome 11. Mol Endocrinol 1988; 2;(2.);186-92. I Article I PubMed

12. Baldwin ET, Bhat TN, Gulnik S, Hosur MV, Sowder RC, 2nd, Cachau RE, et al.: Crystal structures of native and inhibited forms of human cathepsin D: implications for lysosomal targeting and drug design. Proc Natl Acad Sci U S A 1993; 90;(14.);6796-800. I Article I PubMed Abstract | PubMed Full Text

13. Metcalf $P$, Fusek M: Two crystal structures for cathepsin D: the lysosomal targeting signal and active site. EMBO J 1993; 12;(4.);1293-302. | PubMed Abstract | PubMed Full Text

14. Aoyagi T, Morishima H, Nishizawa R, Kunimoto S, Takeuchi T: Biological activity of pepstatins, pepstanone $A$ and partial peptides on pepsin, cathepsin D and renin. J Antibiot (Tokyo) 1972; 25;(12.);689-94. | Article I PubMed

15. Agarwal NS, Rich DH: Inhibition of cathepsin D by substrate analogues containing statine and by analogues of pepstatin. J Med Chem 1986; 29;(12.);2519-24. | Article | PubMed

16. Samarel AM, Ferguson AG, Decker RS, Lesch M: Effects of cysteine protease inhibitors on rabbit cathepsin D maturation. Am J Physiol 1989; 257;(6 Pt 1.);C1069-79. | Article I PubMed

17. Fortenberry SC, Schorey JS, Chirgwin JM: Role of glycosylation in the expression of human procathepsin D. J Cell Sci 1995; 108 ( Pt 5);(20016. | Article | PubMed

18. von Figura K, Hasilik A: Lysosomal enzymes and their receptors. Annu Rev Biochem 1986; 55;(167-93. I Article I PubMed

19. Kornfeld S: Lysosomal enzyme targeting. Biochem Soc Trans 1990; 18;(3.);367-74. I PubMed

20. Rijnboutt S, Aerts HM, Geuze HJ, Tager JM, Strous GJ: Mannose 6-phosphate-independent membrane association of cathepsin D, glucocerebrosidase, and sphingolipid-activating protein in HepG2 cells. J Biol Chem 1991; 266;(8.);4862-8. I Article I PubMed

21. Benes P, Vetvicka V, Fusek M: Cathepsin D--many functions of one aspartic protease. Crit Rev Oncol Hematol 2008; 68;(1.);12-28. I Article | PubMed Abstract | PubMed Full Text

22. Masson O, Bach AS, Derocq D, Prebois C, Laurent-Matha V, Pattingre $\mathrm{S}$, et al.: Pathophysiological functions of cathepsin D: Targeting its catalytic activity versus its protein binding activity? Biochimie 2010; 92;(11.);1635-43. | Article | PubMed

23. Margaryan NV, Kirschmann DA, Lipavsky A, Bailey CM, Hendrix MJ, Khalkhali-Ellis Z: New insights into cathepsin D in mammary tissue development and remodeling. Cancer Biol Ther 2010; 10;(5.);457-66. I Article | PubMed Abstract | PubMed Full Text

24. Saftig P, Hetman M, Schmahl W, Weber K, Heine L, Mossmann H, et al.: Mice deficient for the lysosomal proteinase cathepsin $D$ exhibit progressive atrophy of the intestinal mucosa and profound destruction of lymphoid cells. EMBO J 1995; 14;(15.);3599-608. I PubMed Abstract I PubMed Full Text

25. Koike M, Shibata M, Ohsawa Y, Nakanishi H, Koga T, Kametaka S, et al.: Involvement of two different cell death pathways in retinal atrophy of cathepsin D-deficient mice. Mol Cell Neurosci 2003; 22;(2.);146-61. I Article I PubMed

26. Sagulenko V, Muth D, Sagulenko E, Paffhausen T, Schwab M, Westermann F: Cathepsin D protects human neuroblastoma cells from 
doxorubicin-induced cell death. Carcinogenesis 2008; 29;(10.);1869-77. | Article | PubMed

27. Zhao S, Aviles ER, Jr., Fujikawa DG: Nuclear translocation of mitochondrial cytochrome c, lysosomal cathepsins B and D, and three other death-promoting proteins within the first 60 minutes of generalized seizures. J Neurosci Res 2010; 88;(8.);1727-37. | Article | PubMed

28. Haendeler J, Popp R, Goy C, Tischler V, Zeiher AM, Dimmeler S: Cathepsin $\mathrm{D}$ and $\mathrm{H} 2 \mathrm{O} 2$ stimulate degradation of thioredoxin-1: implication for endothelial cell apoptosis. J Biol Chem 2005; 280;(52.);42945-51. I Article I PubMed

29. van der Hilst JC, Kluve-Beckerman B, van der Meer JW, Simon A: Cathep$\sin D$ activity protects against development of type $A A$ amyloid fibrils. Eur J Clin Invest 2009; 39;(5.);412-6. | Article | PubMed

30. Reid WA, Valler MJ, Kay J: Immunolocalization of cathepsin D in normal and neoplastic human tissues. J Clin Pathol 1986; 39;(12.);1323-30. I Article | PubMed Abstract | PubMed Full Text

31. Spyratos F, Maudelonde T, Brouillet JP, Brunet M, Defrenne A, Andrieu C, et al.: Cathepsin $\mathrm{D}$ : an independent prognostic factor for metastasis of breast cancer. Lancet 1989; 2;(8672.);1115-8. | Article | PubMed

32. Leto G, Gebbia N, Rausa L, Tumminello FM: Cathepsin D in the malignant progression of neoplastic diseases (review). Anticancer Res 1992; 12;(1.);235-40. | PubMed

33. Rochefort H: Cathepsin $D$ in breast cancer: a tissue marker associated with metastasis. Eur J Cancer 1992; 28A;(11.);1780-3. | PubMed

34. Rochefort $\mathrm{H}$ : Biological and clinical significance of cathepsin $\mathrm{D}$ in breast cancer. Acta Oncol 1992; 31;(2.);125-30. | Article | PubMed

35. Tedone T, Correale M, Barbarossa G, Casavola V, Paradiso A, Reshkin SJ: Release of the aspartyl protease cathepsin $D$ is associated with and facilitates human breast cancer cell invasion. FASEB J 1997; 11;(10.);78592. | Article | PubMed

36. Johnson MD, Torri JA, Lippman ME, Dickson RB: The role of cathepsin $D$ in the invasiveness of human breast cancer cells. Cancer Res 1993; 53;(4.);873-7. | Article | PubMed

37. Lah TT, Calaf G, Kalman E, Shinde BG, Russo J, Jarosz D, et al.: Cathepsins $D, B$ and $L$ in breast carcinoma and in transformed human breast epithelial cells (HBEC). Biol Chem Hoppe Seyler 1995; 376;(6.);357-63. I PubMed

38. Conner GE: Isolation of procathepsin $D$ from mature cathepsin $D$ by pepstatin affinity chromatography. Autocatalytic proteolysis of the zymogen form of the enzyme. Biochem J 1989; 263;(2.);601-4. I PubMed Abstract | PubMed Full Text

39. Wittlin S, Rosel J, Hofmann F, Stover DR: Mechanisms and kinetics of procathepsin D activation. Eur J Biochem 1999; 265;(1.);384-93. I Article I PubMed

40. Glondu M, Coopman P, Laurent-Matha V, Garcia M, Rochefort H, LiaudetCoopman E: A mutated cathepsin-D devoid of its catalytic activity stimulates the growth of cancer cells. Oncogene 2001; 20;(47.);6920-9. | Article | PubMed

41. Nirde P, Derocq D, Maynadier M, Chambon M, Basile I, Gary-Bobo M, et al.: Heat shock cognate $\mathbf{7 0}$ protein secretion as a new growth arrest signal for cancer cells. Oncogene 2010; 29;(1.);117-27. | Article I PubMed Abstract | PubMed Full Text

42. Vetvicka V, Benes P, Fusek M: Procathepsin D in breast cancer: what do we know? Effects of ribozymes and other inhibitors. Cancer Gene Ther 2002; 9;(10.);854-63. | Article | PubMed

43. Glondu M, Liaudet-Coopman E, Derocq D, Platet N, Rochefort H, Garcia $M$ : Down-regulation of cathepsin-D expression by antisense gene transfer inhibits tumor growth and experimental lung metastasis of human breast cancer cells. Oncogene 2002; 21;(33.);5127-34. | Article I PubMed

44. Vetvicka V, Vetvickova J, Fusek M: Anti-human procathepsin D activation peptide antibodies inhibit breast cancer development. Breast Cancer Res Treat 1999; 57;(3.);261-9. | Article | PubMed

45. Fusek M, Vetvicka V: Mitogenic function of human procathepsin D: the role of the propeptide. Biochem J 1994; 303 ( Pt 3);(775-80. | PubMed Abstract | PubMed Full Text

46. Vetvicka V, Vetvickova J, Fusek M: Effect of procathepsin D and its activation peptide on prostate cancer cells. Cancer Lett 1998; 129;(1.);55-9. | Article | PubMed

47. Vetvicka $V$, Vetvickova J, Fusek M: Role of procathepsin D activation peptide in prostate cancer growth. Prostate 2000; 44;(1.);1-7. | Article I PubMed

48. Vetvicka V, Vetvickova J, Benes P: Role of enzymatically inactive procathepsin D in lung cancer. Anticancer Res 2004; 24;(5A.);2739-43. Article | PubMed

49. Garcia M, Derocq D, Pujol P, Rochefort H: Overexpression of transfected cathepsin $D$ in transformed cells increases their malignant phenotype and metastatic potency. Oncogene 1990; 5;(12.);1809-14. | PubMed

50. Vetvicka V, Fusek M. Procathepsin D and human cancer. Curr.Top. Pept. Prot. Res. 2004; 6: 93-99.

51. Vetvicka V, Benes P, Fusek M: Procathepsin D in breast cancer: what do we know? Effects of ribozymes and other inhibitors. Cancer Gene Ther 2002; 9;(10.);854-63. | Article | PubMed

52. Vashishta A, Ohri SS, Proctor M, Fusek M, Vetvicka V: Role of activation peptide of procathepsin $D$ in proliferation and invasion of lung cancer cells. Anticancer Res 2006; 26;(6B.);4163-70. | Article | PubMed

53. Selicharova I, Sanda M, Mladkova J, Ohri SS, Vashishta A, Fusek M, et al.: 2-DE analysis of breast cancer cell lines 1833 and 4175 with distinct metastatic organ-specific potentials: comparison with parental cell line MDA-MB-231. Oncol Rep 2008; 19;(5.);1237-44. | Article | PubMed

54. Vashishta A, Ohri SS, Proctor M, Fusek M, Vetvicka V: Ribozymetargeting procathepsin $D$ and its effect on invasion and growth of breast cancer cells: an implication in breast cancer therapy. Int $J$ Oncol 2007; 30;(5.);1223-30. | Article | PubMed

55. Ohri SS, Vashishta A, Proctor M, Fusek M, Vetvicka V: The propeptide of cathepsin $D$ increases proliferation, invasion and metastasis of breast cancer cells. Int J Oncol 2008; 32;(2.);491-8. | Article I PubMed

56. Ohri SS, Vashishta A, Vetvickova J, Fusek M, Vetvicka V: Procathepsin D expression correlates with invasive and metastatic phenotype of MDA-MB-231 derived cell lines. Int J Biol Macromol 2007; 41;(2.);204-9. | Article | PubMed

57. Ohri SS, Vashishta A, Proctor M, Fusek M, Vetvicka V: Depletion of procathepsin $D$ gene expression by RNA interference: a potential therapeutic target for breast cancer. Cancer Biol Ther 2007; 6;(7.);1081-7. | Article | PubMed

58. Beaujouin M, Prebois C, Derocq D, Laurent-Matha V, Masson O, Pattingre $S$, et al.: Pro-cathepsin $D$ interacts with the extracellular domain of the beta chain of LRP1 and promotes LRP1-dependent fibroblast outgrowth. J Cell Sci 2010; 123;(Pt 19.);3336-46. | Article | PubMed Abstract | PubMed Full Text

59. Beaujouin M, Baghdiguian S, Glondu-Lassis M, Berchem G, LiaudetCoopman E: Overexpression of both catalytically active and -inactive cathepsin $D$ by cancer cells enhances apoptosis-dependent chemo-sensitivity. Oncogene 2006; 25;(13.);1967-73. | Article | PubMed Abstract | PubMed Full Text

60. Vetvicka V, Fusek M, Vashishta A: Procathepsin d involvement in chemoresistance of cancer cells. N Am J Med Sci 2012; 4;(4.);174-9. | Article | PubMed Abstract | PubMed Full Text

61. Nadji M, Fresno M, Nassiri M, Conner G, Herrero A, Morales AR: Cathepsin $D$ in host stromal cells, but not in tumor cells, is associated with aggressive behavior in node-negative breast cancer. Hum Pathol 1996; 27;(9.);890-5. | Article | PubMed

\section{Citation:}

Vetvicka V: Procathepsin D in cancer development. journal of Cancer Therapeutics and Research 2012, 1:22. http://dx.doi.org/10.7243/2049-7962-1-22 